\title{
Modelling of Rehydration Kinetics of Desert Truffles (Terfezia spp.) Dried by Microwave Oven
}

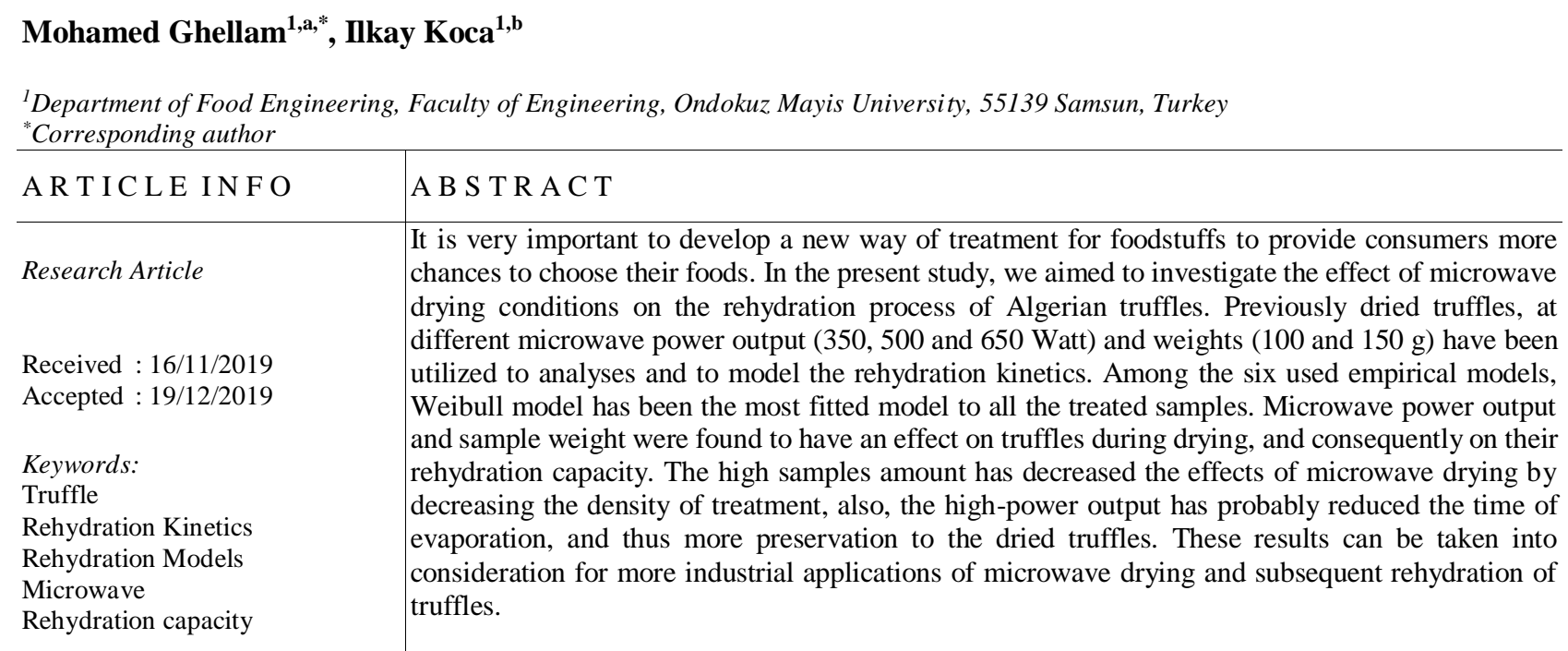

\section{Introduction}

Truffles are also known as Terfas in the north of Africa, Kames or Kame in western Asia or Toprak Mantari in Turkish which means word for word, earth mushroom. Truffles have been used for a long time after their dehydration by Arabs for their supplies (Chatin, 1891; Chatin, 1892). In spite of the common high prices, because of their scarcity, truffles are very popular even outside their origin countries due to their nutritional value and high palatability (Mandeel and Al-Laith, 2007).

Generally, truffles are found in many types of ecosystems encompassing, groves, forests, arid areas and deserts as well (Trappe and Castellano, 1991). Usually, the truffle season in these areas lasts only a few weeks and their harvests are influenced by precipitation (Chatin, 1891; Chatin, 1892). Desert truffles are endemic in the Mediterranean region and they can be found in mycorrhizal association with specific hosts (Díez et al., 2002). Many species from the genera Terfezia, Timania and Picoa are included under the name of Terfez or Terfas (ZitouniHaouar et al., 2014).

In Algeria, similarly to other countries, the hunting of this hypogeous fungi still applied by experimented and nomad people who know its hidden places. Truffles are distinguished by their host plants, cracks, and swellings that typically cause on the ground. (Bradai et al., 2013;
Bradai et al., 2015a). Furthermore, some European countries use animals to discern this precious food (Dafri and Beddiar, 2017).

Desert truffles are an important resource for social and financial life of local inhabitants of containing regions. Besides their uses as a food, they are believed to have a beneficial activity to increase fertility and to have an action against eye diseases and fatigue (Bradai et al., 2015b). These functional allegations could be linked to their antibacterial and antioxidants properties which have roles to prevent health from various diseases and ailments (Shavit and Shavit, 2014). This could be compared to some mushroom types who described the high antioxidant potential to reduce the negative effects of oxidative stresses (Bal et al., 2017). In addition to their nutritional aspect, these natural sources can be used due to their potential health protection activities in many fields of application such as medicine, pharmacology, and cosmetics (Sevindik et al., 2018).

Because of the high water content, truffles are very perishable and cannot be stored for long time. In order to increase their shelf life for storage many treatment and pretreatment have been applied such as blanching, salting, vinegar addition, convective drying, freezing, freezedrying, modified atmosphere packaging and irradiation. 
Many studies have tested these techniques to improve the preservation of truffles. The results were interesting to choose the appropriate treatment to extend the shelf life and to obtain the best preservation of quality (texture, colour, aromatic and microbial profiles) (Al-Ruqaie, 2006; Palacios et al., 2014; Reale et al., 2009; Rivera et al., 2010).

One of those methods is drying which is one of the fundamental operations used in the food industry principally to preserve perishable foodstuffs, increasing their shelf lives and thus covering the increasing demand of market on food. Since ancient time, drying or dehydration has helped peasants and farmers to preserve their crops. This operation has been used for many foodstuffs such as meats, dairy foods, mushrooms, fruits, and vegetables (Saguy et al., 2010).

Till today, various techniques have been applied to decrease the water content of foods, even so, their water activity. Recently, microwave drying has started to be one of these techniques, its application has been studied for many types of foodstuffs. This technique has shown positive results by assisting other types of drying or as a principal method of drying. It helps to provide clean energy with less power, in tight space and in a shorter time (Arballo et al., 2010; Dev et al., 2011).

Generally, in order to regenerate and reconstitute dried foods, rehydration is an inevitable process. The control of dehydration and rehydration processes became necessary since consumers wait to have a rehydrated product with similar characteristics of the fresh ones, (Marabi et al., 2003; Saguy et al., 2010). The rehydration is the process to immerse an already dried product in a liquid medium. The conditions and type of dehydration process, principally that of temperature, seemed to have an effect not only during dehydration but even for rehydration of the dried food products. Also, the rehydration conditions have shown actions on rehydration kinetics and on properties of the final rehydrated products (Krokida and Philippopoulos, 2005; Kowalska et al., 2018).

In this work, an Algerian desert truffle (Terfezia spp.) had been dried in microwave at different output powers. This study aimed to investigate the drying effects of microwave power output on the truffles and their amounts by applying a subsequent rehydration process. Many mathematical models have been applied to analyse the rehydration kinetics for each group of drying treatment. To the best of our knowledge, this paper can be considered as the first study to model the rehydration kinetics of microwave dried truffles.

\section{Materials and Methods}

\section{Samples and Drying Conditions}

To study the drying conditions factors effects on rehydration, desert truffles (Terfezia claveryi), locally called Terfas Lakhal (Bradai, 2014), were collected from a local market in the wilaya of Ouargla, Algeria (32²9'24.1"N 546'46.2"E). Truffles had been dried by microwave oven (Arçelik MD581 Model, Turkey) depending on sample weights $(100 \mathrm{~g}$ and $150 \mathrm{~g})$ and microwave power $(350,500$ and $650 \mathrm{~W})$. Dried truffles were tightly stored in glass containers at $4^{\circ} \mathrm{C}$.

\section{Moisture Content}

Dried truffles at different conditions ( $5 \mathrm{~g}$ ) have been rehydrated by immersing in $200 \mathrm{ml}$ of distillate water $(1: 40)$ at room temperature $\left(20 \pm 2^{\circ} \mathrm{C}\right)$. with an accuracy of 0.001 of analytic balance (RADWAG, AS 220/C/2 model), the samples were periodically (every 1 hour) weighed after being carefully plotted with tissue paper to remove the superficial water. The samples are kept immersed in water until no further changes in weight was observed (equilibrium point). According to Pramiu et al. (2015), the moisture content was measured on a dry basis as it is presented in equation (1):

$$
M(t)=\frac{w_{s}(t)-w_{d m}}{W_{d m}}
$$

Where $\mathrm{M}(\mathrm{t})$ is the moisture content in decimal dry basis (db.) at time $t ; W_{s}(t)$ is the mass of the sample at time $t$ and $\mathrm{W}_{\mathrm{dm}}$ is the dry mass for treatment.

\section{Rehydration Capacity $(\boldsymbol{R C})$}

The rehydration capacity of dried truffles is calculated when they reached the equilibrium (Aral and Beşe, 2016). The equation (2) is as follows:

$$
\mathrm{RC}=\frac{\mathrm{W}_{\text {eight }} \text { of rehydrated samples }(\mathrm{g})}{\mathrm{W}_{\text {eight }} \text { of dried samples }(\mathrm{g})}
$$

\section{Rehydration Kinetic Models}

Generally, in previous studies several empirical models are used for the modelling of rehydration process. Commonly used models for controlling and describing the rehydration mechanism are given in Table 1.

Table 1. Different mathematical models for rehydration kinetics

\begin{tabular}{l|cc}
\hline \multicolumn{1}{c|}{ Model Name } & Model Equation & References \\
\hline Peleg & $\mathrm{M}(\mathrm{t})=\mathrm{M}_{0}+\left(\frac{\mathrm{t}}{\mathrm{a}+\mathrm{b} t}\right)$ & Peleg, 1988 \\
Weibull & $\mathrm{M}(\mathrm{t})=\mathrm{M}_{\mathrm{eq}}+\left(\mathrm{M}_{0}-\mathrm{M}_{\mathrm{eq}}\right) \exp \left(-\left(\frac{\mathrm{t}}{\mathrm{b}}\right)^{\mathrm{a}}\right)$ & Vega-Gálvez et al., 2009 \\
First Order Kinetic & $\mathrm{M}(\mathrm{t})=\mathrm{M}_{\mathrm{eq}}+\left(\mathrm{M}_{0}-\mathrm{M}_{\mathrm{eq}}\right) \exp (-\mathrm{a} \mathrm{t})$ & Krokida and Marinos-Kouris, \\
Exponential Model & $\mathrm{M}(\mathrm{t})=\mathrm{M}_{\mathrm{eq}}+\left(\mathrm{M}_{0}-\mathrm{M}_{\mathrm{eq}}\right) \exp \left(-\mathrm{a} \mathrm{t}^{\mathrm{k}}\right)$ & 2003 \\
Proposed Model & $\mathrm{M}(\mathrm{t})=\mathrm{a} \exp \left(-\frac{\mathrm{b}}{(1+\mathrm{t})^{\mathrm{k}}}\right)$ & Saguy et al., 2005 \\
$\begin{array}{l}\text { Exponential Related } \\
\text { Equation }\end{array}$ & $\mathrm{M}(\mathrm{t})=\mathrm{M}_{\mathrm{eq}}(1-\exp (-\mathrm{at}))$ & Noshad et al., 2012, 2009 \\
\hline
\end{tabular}




\section{Peleg}

The model proposed by Peleg. (1988), is one of empirical models applied to examine the rehydration kinetics. This model had been used for the hydration of different foodstuffs (Moreira et al., 2008; Goula and Adamopoulos., 2009; Noshad et al., 2012; Pramiu et al., 2015; Yalçin et al., 2018). This model's equation exhibits a simple calculation compared to rest of models in which it could be transformed into linear relationship (GarcíaSegovia et al., 2011). The equation, as it is shown in Table 1, consists of:

$$
\begin{array}{ll}
\mathrm{t} & =\text { Time (minutes) } \\
\mathrm{M}(\mathrm{t}) & =\text { Average moisture content at time } \mathrm{t},(\mathrm{g} \text { water } / \mathrm{g} \mathrm{db} .) \\
\mathrm{M}_{0} & =\text { Initial moisture }(\mathrm{t}=0), \% \text { weight on dry basis } \\
\mathrm{a} & =\text { Peleg rate constant, minutes per } \% \text { weight } \\
\mathrm{b} & =\text { Peleg capacity constant, reciprocal of } \% \text { on dry } \\
& \text { weight basis }
\end{array}
$$

\section{Weibull}

Weibull is another widely proposed empirical model (García-Segovia et al., 2011; Pramiu et al., 2015). This probabilistic model is employed in rehydration kinetics due to its mathematical simplicity, utility, and flexibility in the estimation of its kinetic parameters. In general, it has been found for wide applications of food engineering (Diaz et al., 2003; Dadali et al., 2008; Goula and Adamopoulos, 2009; García-Segovia et al., 2011; Noshad et al., 2012; Benseddik et al. 2018). Where:

$$
\begin{aligned}
& \mathrm{t} \quad=\text { Time (minutes) } \\
& \mathrm{M}(\mathrm{t})=\text { Average moisture content at time } \mathrm{t},(\mathrm{g} \text { water/g db.) } \\
& \mathrm{M}_{0} \quad=\text { Initial moisture }(\mathrm{g} \text { water/g db. }) \\
& \mathrm{M}_{\text {eq }}=\text { Equilibrium moisture content }(\mathrm{g} \text { water/g db.) } \\
& \mathrm{a} \quad=\text { Shape parameter } \\
& \mathrm{b} \quad=\text { Rate(scale) parameter }
\end{aligned}
$$

\section{First Order Kinetic}

First order kinetic model is also commonly preferred to examine and describe moisture transfer kinetics during rehydration (Krokida and Marinos-Kouris, 2003; GarcíaSegovia et al., 2011). Different studies have applied this equation in the fitting of rehydration for dried foodstuffs (Noshad et al., 2012; Yalçin et al., 2018). Where:

$\mathrm{t} \quad=$ Time (minutes)

$\mathrm{M}(\mathrm{t})=$ Average moisture content at time $\mathrm{t},(\mathrm{g}$ water/g db.)

$\mathrm{M}_{0}=$ Initial moisture (dry material) (g water/g db.)

$\mathrm{M}_{\mathrm{eq}}=$ Equilibrium moisture content ( $\mathrm{g}$ water/g db.

a $=$ Rehydration rate $\left(\mathrm{min}^{-1}\right)$ determined as the slope of the falling rate rehydration curve.

\section{Exponential Model}

Exponential model is presented by the equation of thinlayer rewetting. This model is also utilized for the modeling in rehydration of food materials (Saguy et al., 2005; Benseddik et al 2018; Lopez-Quiroga et al., 2019). If " $\mathrm{k}$ " is equal to 1 , the exponential model leads to a first order kinetic expression. Where:

$\mathrm{t} \quad=$ Time (minutes)

$\mathrm{M}(\mathrm{t})=$ Average moisture content at time $\mathrm{t},(\mathrm{g}$ water/g db. $)$

$\mathrm{M}_{0}=$ Initial moisture (dry material) (g water/g db.)

$\mathbf{M}_{\text {eq }}=$ Equilibrium moisture content ( $\mathrm{g}$ water/g db.)

$\mathrm{a}=$ Rehydration rate $\left(\mathrm{min}^{-1}\right)$ determined as the slope of the falling rate rehydration curve

$\mathrm{k} \quad=$ Rehydration parameter

\section{Proposed model}

It is a new mathematical model. it had been proposed by Vega-Gálvez et al. (2009).

$\mathrm{t} \quad=$ Time (minutes)

$\mathrm{M}(\mathrm{t})=$ Average moisture content at time $\mathrm{t}$, (g water/g db.)

$\mathrm{a}, \mathrm{b}$, and $\mathrm{k}$ are kinetic constants of models, superior than 0 .

\section{Exponential related model}

Another model has been applied for food rehydration kinetics (Noshad et al 2012; Yalçin et al., 2018). Exponential association equation as it is shown in Table 1. Where:

$$
\begin{aligned}
& \mathrm{t} \quad=\text { Time (minutes) } \\
& \mathrm{M}(\mathrm{t})=\text { Average moisture content at time } \mathrm{t},(\mathrm{g} \text { water/g db. }) \\
& \mathrm{M}_{\mathrm{eq}}=\text { Equilibrium moisture content }(\mathrm{g} \text { water/g db. }) \\
& \mathrm{a} \quad=\text { Kinetic constant }\left(\mathrm{min}^{-1}\right)
\end{aligned}
$$

\section{Data Statistical Analysis}

The experimental results of rehydration for dried truffles at different power $(350 \mathrm{~W}, 500 \mathrm{~W}$, and $650 \mathrm{~W})$ were fitted with empirical models. The fitting was coded using software MATLAB version 8.5.

In order to assess the fitting quality and to evaluate the goodness of fit of each model, four criteria were used: linear regression coefficient $\left(\mathrm{R}^{2}\right)$, root mean square error (RMSE), sum of square error (SSE) and Chi-square $\left(\mathrm{X}^{2}\right)$. The equations of last three statistical tests are presented in Eq. (3), Eq. (4), and Eq. (5), respectively. The optimum models are chosen according to highest value of $\mathrm{R}^{2}$ and the lowest values of RMSE, SSE, and $\mathrm{X}^{2}$.

$$
\begin{aligned}
& \mathrm{SSE}=\frac{1}{\mathrm{~N}} \sum_{\mathrm{i}=1}^{\mathrm{N}}(\mathrm{Mei}-\mathrm{Mci})^{2} \\
& \mathrm{RMSE}=\left[\frac{1}{\mathrm{~N}} \sum_{\mathrm{i}=1}^{\mathrm{N}}(\mathrm{Mci}-\mathrm{Mei})^{2}\right]^{1 / 2} \\
& \mathrm{x}^{2}=\frac{\sum_{\mathrm{i}=1}^{\mathrm{N}}(\mathrm{Mci}-\mathrm{Mei})^{2}}{\mathrm{~N}-\mathrm{z}}
\end{aligned}
$$

Where $M \mathrm{ci}$ is the calculated moisture content ( $\mathrm{g}$ water/g $\mathrm{db}$.), Mei is the experimental moisture content (g water/g db.), $\mathrm{z}$; number of constants, and $\mathrm{N}$ number of data (VegaGálvez et al., 2009).

\section{Results and Discussion}

\section{Rehydration Curves and Capacity}

The truffle samples (A1, A2, B1, B2, C1, C2) which have been early dried by using 3 microwave output powers $(350,500$ and $650 \mathrm{~W})$ for 2 different quantities (100 and $150 \mathrm{~g}$ ) are rehydrated at ambient temperature (Table 2). Figure 1 represents the rehydration curves (rehydration ration versus time in minute), these moisture contents have been calculated in dry basis.

Through the obtained curves, the rehydration rate has shown for the first hour $(60 \mathrm{~min})$ a rapid moisture intake for all samples. Almost for all samples, the water absorption rate has slowed down by approaching the equilibrium, after 300 minutes. 
Table 2. Microwave power density and moisture contents for each treatment.

\begin{tabular}{l|cccccc}
\hline \multicolumn{1}{c|}{ Treatment } & $\mathrm{A} 1$ & $\mathrm{~A} 2$ & $\mathrm{~B} 1$ & $\mathrm{~B} 2$ & $\mathrm{C} 1$ & $\mathrm{C} 2$ \\
\hline Power output Watt/ weight Gram $(\mathrm{W} / \mathrm{g})$ & $350 \mathrm{~W} / 100 \mathrm{~g}$ & $350 \mathrm{~W} / 150 \mathrm{~g}$ & $500 \mathrm{~W} / 100 \mathrm{~g}$ & $500 \mathrm{~W} / 150 \mathrm{~g}$ & $650 \mathrm{~W} / 100 \mathrm{~g}$ & $650 \mathrm{~W} / 150 \mathrm{~g}$ \\
Microwave power density (W/g) & 3.5 & 2.33 & 5 & 3.33 & 6.5 & 4.33 \\
Moisture contents in equilibrium & $1.14 \pm 0.020$ & $1.21 \pm 0.014$ & $1.18 \pm 0.021$ & $1.21 \pm 0.002$ & $1.10 \pm 0.012$ & $1.35 \pm 0.005$ \\
\hline
\end{tabular}

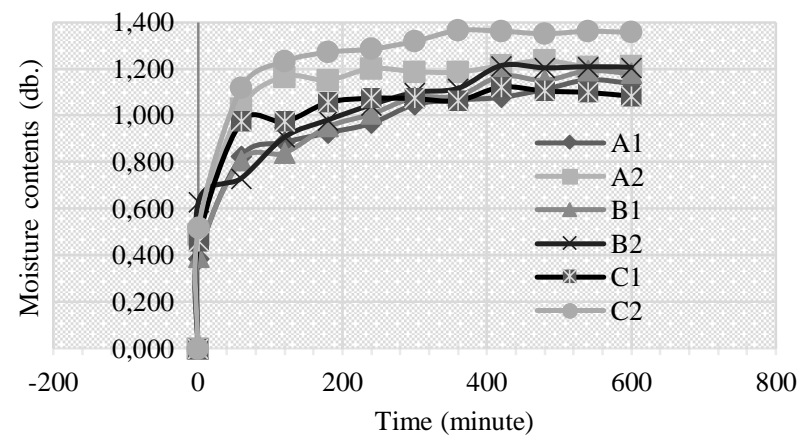

Figure 1. Rehydration curves

At the beginning of the rehydration process, the rapid water uptake was possibly due to the filling of surface cavities (intracellular spaces) of hyphae. After the first hour, the rate decreases until equilibrium, this explains that the water movement inside the hyphae has been reduced. Probably, this could be occurred firstly due to saturation of outer cavities or/and to the existing trapped air bubbles, which all hinder the free movement of water (García-Pascual et al., 2006; García-Segovia et al., 2011; Asadi et al., 2018).

As it is shown in Figure 2, in general the microwave power density has shown different rehydration capacities. The decreasing of dehydration power density $(\mathrm{W} / \mathrm{g})$ by increasing samples weight has increased the capacity of rehydration. For instance, A1 samples have less rehydration capacity compared to $\mathrm{A} 2$ at the same power treatment. Furthermore, the capacity of $\mathrm{C} 1$ samples has shown the lowest capacity (2.08) compared to all weights for the other treatment powers. However, for C2 samples showed the highest rehydration capacity compared to all treatments and weights samples.

After that, it can be seen that the dehydration power density has a crucial role in the rehydration process. The high power had affected the samples leading to deteriorations and modifications of dried truffles. As the truffles are a rich source of protein $(19-27 \%)$ and dietary fibers (8-15\%) (Hussain and Al-Ruqaie, 1999; Patel et al., 2017), the structure of truffles would be changed at high temperatures resulted from the high treatment power.

The moisture contents in equilibrium are between 1.10 and 1.35 decimal dry basis, for $\mathrm{C} 1, \mathrm{C} 2$ successively. It can be seen that the weight of samples has affected the rehydration and the quantity of absorbed water. Samples treated of $150 \mathrm{~g}$ have shown the high moisture contents values, this probably could happen due to the ratio of microwave power (W) to weight of samples (g). Maybe the high quantity has participated to decrease the effect of energy that would alter the truffles structure during drying and consequently affecting the ulterior rehydration.

The denaturation of protein and deterioration of polymers structure are probably the main factors that have affected negatively the absorbing and binding ability of rehydration water and consequently, that influenced the rehydration capacity (Marabi et al., 2003; Kocabay and Ismail, 2017). Unfortunately, these kinds of damages are irreversible which

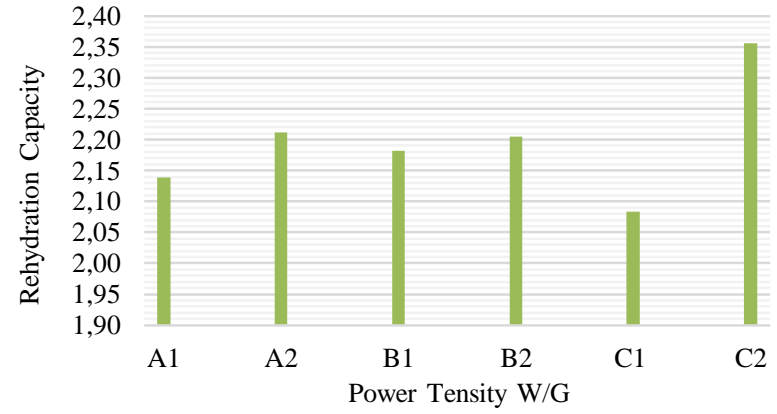

Figure 2. Rehydration capacity of different samples

cannot give back the initial structure of fresh materials (VegaGálvez et al., 2009). This had been encountered for many foodstuffs and mushrooms which have a close structure to truffles, like in air-dried Shiitake mushrooms (García-Segovia et al., 2011), morel mushrooms (García-Pascual et al., 2006) oyster mushrooms (Kotwaliwale et al., 2007), as well as microwave-vacuum dried button mushrooms, by which it was found a fast dehydration process comparing to air-drying and subsequently a better rehydration. Giri and Prasad, (2007) have revealed too that microwave power and sample thickness affect the rate of drying, evidently the low time of processing the less structural damages by thermal treatment. So, rehydration capacity, in spite of being a complex operation, it can be used as measure mean of damages engendered during drying treatment (Saguy et al., 2010; Benseddik et al. 2018).

\section{Rehydration Kinetics}

Table 3 shows the result values of 6 models describing the corresponding parameters $(\mathrm{a}, \mathrm{b}, \mathrm{k})$ as well as the regression coefficient $\left(\mathrm{R}^{2}\right)$, root mean square error (RMSE), sum of square error (SSE) and Chi-square $\left(\mathrm{X}^{2}\right)$, for the 6 samples. The values of $\mathrm{R}^{2}$ and SSE are taken as the main criterion to choose the good fitting models. The best fitted models should have the highest $\mathrm{R}^{2}$ value and the lowest SSE values.

At first glance, mostly, the highest $\mathrm{R}^{2}$ and the lowest SSE values of samples can be seen with the Weibull model. Furthermore, with this model, $\mathrm{R}^{2}$ values vary between 0.9971 and 0.9054. Although, some models have shown high values with some samples, but they still under that with the Weibull model. The fitted model and experimental curves are presented in Figure 3.

From Table 3, the parameters values of the most fitted model (Weibull) for each treatment are shown. The obtained shape parameter "a" for this model is between 0.2053 and 0.3527. It seems that this parameter may measure the velocity of rehydration at the beginning of the process (Giri and Prasad. 2007). The estimated scale parameters " $b$ " for Weibull model are also given. There was a decreasing in this parameter when the amount increased to $150 \mathrm{~g}$ at constant output powers (A2, B2). However, C2 has shown an increase in this parameter. Scale parameter was previously linked to internal diffusion which could have an important role in rehydration processes (Dadali et al., 2008). 
Many drying and rehydration studies have been applied on various type of fruits, vegetables and other foodstuffs. Globally, they wanted to understand the kinetics of theses samples with different techniques and to model them at different levels and conditions of treatment. Microwave drying is being one of them to substitute the conventional drying. For instance, the study of Diaz et al., (2003) on orange slices, Dadali et al. (2007) and Dadali et al. (2008) on spinach, Zielinska and Markowski, (2016) on blueberry, Maskan, M. (2001) and Akar and BarutçuMazı, (2019) on kiwifruits and so on.

In literature, because of the absence of works on truffles dehydration and their rehydration, mushrooms can be a good example to be compared to, due to the close physical structure (hyphae). García-Segovia et al. (2011) have carried out a study on air-dried Shiitake mushroom to compare their conventional and vacuum technic rehydration. In spite of using three models; Pledge, Weibull, and first-order kinetics, it seemed that the Weibull models had been the well-fitted model to almost all the samples for both treatments, where its $\mathrm{R}^{2}$ values were between 0.966 and 0.999 . It had been found that rehydration capacity of mushrooms was a temperature and pressure-dependent. It was evident that the models' parameters were also related to them.

Also, in order to model the rehydration kinetics of Boletus edulis mushrooms (García-Pascual et al., 2005), Peleg's and Weibull's models have been applied. In addition to the influence of rehydration temperature on the equilibrium moisture content, the rehydration parameters "a" and "b", for Peleg and Weibull models respectively, had shown no influence on the drying temperature. However, they had on those of rehydration. It was mentioned that the kinetics of this complex process is dependently linked to the drying process, where the disruption and structural change would reduce the hydrophilic properties and the final rehydration ability. Not far, a similar study of GarcíaPascual et al. (2006) on Morchella esculenta mushrooms, has also found that those both empirical models had properly described the experimental data. Furthermore, the rehydration temperatures had a linear relationship with kinetic parameters except that of $70^{\circ} \mathrm{C}$.

Table 3. Rehydration fitting results for all samples with the six models

\begin{tabular}{|c|c|c|c|c|c|c|c|}
\hline Model Name & & A1 & $\mathrm{A} 2$ & $\mathrm{~B} 1$ & $\mathrm{~B} 2$ & $\mathrm{C} 1$ & $\mathrm{C} 2$ \\
\hline \multirow{6}{*}{ Peleg } & $\mathrm{R}^{2}$ & 0.9240 & 0.9856 & 0.8907 & 0.8329 & 0.9855 & 0.9775 \\
\hline & SSE & 0.1012 & 0.0230 & 0.1596 & 0.2227 & 0.0186 & 0.0449 \\
\hline & RMSE & 0.1006 & 0.0480 & 0.1263 & 0.1492 & 0.0431 & 0.0670 \\
\hline & $\mathrm{X}^{2}$ & 0.0101 & 0.0023 & 0.0160 & 0.0223 & 0.0019 & 0.0045 \\
\hline & Model & $\mathrm{a}=2.0292$ & $\mathrm{a}=1.2888$ & $\mathrm{a}=1.9536$ & $a=0.51563$ & $\mathrm{a}=1.3064$ & $\mathrm{a}=1.2502$ \\
\hline & constants & $\mathrm{b}=0.9879$ & $\mathrm{~b}=0.8491$ & $\mathrm{~b}=0.9499$ & $b=0.9372$ & $\mathrm{~b}=0.9403$ & $\mathrm{~b}=0.7639$ \\
\hline \multirow{6}{*}{ Weibull } & $\mathrm{R}^{2}$ & 0.9815 & 0.9971 & 0.9719 & 0.9054 & 0.9956 & 0.9964 \\
\hline & SSE & 0.0246 & 0.0047 & 0.0411 & 0.1261 & 0.0057 & 0.0072 \\
\hline & RMSE & 0.0496 & 0.0217 & 0.0641 & 0.1123 & 0.0238 & 0.0268 \\
\hline & $\mathrm{X}^{2}$ & 0.0025 & 0.0005 & 0.0041 & 0.0126 & 0.0006 & 0.0007 \\
\hline & Model & $a=0.3407$ & $\mathrm{a}=0.3527$ & $a=0.3412$ & $a=0.2053$ & $a=0.3407$ & $\mathrm{a}=0.3499$ \\
\hline & constants & $b=23.7691$ & $b=7.3225$ & $\mathrm{~b}=33.3313$ & $b=5.9516$ & $b=6.3606$ & $b=9.1300$ \\
\hline \multirow{5}{*}{$\begin{array}{l}\text { First Order } \\
\text { Kinetic }\end{array}$} & $\mathrm{R}^{2}$ & 0.8138 & 0.9713 & 0.7060 & 0.6901 & 0.9730 & 0.9566 \\
\hline & SSE & 0.2479 & 0.0460 & 0.4291 & 0.4131 & 0.0347 & 0.0868 \\
\hline & RMSE & 0.1501 & 0.0647 & 0.1975 & 0.1938 & 0.0561 & 0.0888 \\
\hline & $\mathrm{X}^{2}$ & 0.0225 & 0.0042 & 0.0390 & 0.0376 & 0.0032 & 0.0079 \\
\hline & $\begin{array}{l}\text { Model } \\
\text { constant }\end{array}$ & $a=0.5062$ & $a=0.7288$ & $a=0.3903$ & $\mathrm{a}=0.8839$ & $\mathrm{a}=0.5389$ & $\mathrm{a}=0.4801$ \\
\hline \multirow{6}{*}{$\begin{array}{l}\text { Exponential } \\
\text { Model }\end{array}$} & $\mathrm{R}^{2}$ & 0.9593 & 0.9907 & 0.7060 & 0.8832 & 0.9913 & 0.9877 \\
\hline & SSE & 0.0541 & 0.0149 & 0.4291 & 0.1558 & 0.0112 & 0.0245 \\
\hline & RMSE & 0.0736 & 0.0386 & 0.2071 & 0.1248 & 0.0335 & 0.0495 \\
\hline & $\mathrm{X}^{2}$ & 0.0054 & 0.0015 & 0.0429 & 0.0156 & 0.0011 & 0.0025 \\
\hline & Model & $\mathrm{a}=1.1952$ & $a=0.92638$ & $\mathrm{a}=1.1297$ & $\mathrm{a}=0.61997$ & $a=0.88478$ & $\mathrm{a}=0.9842$ \\
\hline & constants & $\mathrm{k}=0.4210$ & $\mathrm{k}=-0.6095$ & $\mathrm{k}=-7.0621$ & $\mathrm{k}=-0.2896$ & $\mathrm{k}=-0.5775$ & $\mathrm{k}=-0.5459$ \\
\hline \multirow{5}{*}{$\begin{array}{l}\text { Exponential } \\
\text { Related } \\
\text { Equation }\end{array}$} & $\mathrm{R}^{2}$ & 0.8141 & 0.9714 & 0.7061 & 0.6070 & 0.9731 & 0.9566 \\
\hline & SSE & 0.2475 & 0.0459 & 0.4291 & 0.5239 & 0.0346 & 0.0868 \\
\hline & RMSE & 0.1500 & 0.0646 & 0.1975 & 0.2182 & 0.0561 & 0.0888 \\
\hline & & 0.0225 & 0.0042 & 0.1975 & 0.0476 & 0.0031 & 0.0079 \\
\hline & $\begin{array}{l}\text { Model } \\
\text { constant }\end{array}$ & $a=0.4143$ & $a=0.5146$ & $a=0.3959$ & $\mathrm{a}=0.0118$ & $\mathrm{a}=0.5454$ & $\mathrm{a}=0.4827$ \\
\hline \multirow{7}{*}{ Proposed Model } & $\mathrm{R}^{2}$ & 0.9608 & 0.9812 & 0.9587 & 0.8342 & 0.9818 & 0.9674 \\
\hline & SSE & 0.0522 & 0.0302 & 0.0603 & 0.2210 & 0.0234 & 0.0651 \\
\hline & RMSE & 0.0762 & 0.0579 & 0.0819 & 0.1567 & 0.0510 & 0.0851 \\
\hline & $\mathrm{X}^{2}$ & 0.0058 & 0.0034 & 0.0067 & 0.0246 & 0.0026 & 0.0072 \\
\hline & Model & $\mathrm{a}=1.622$ & $\mathrm{a}=1.1785$ & $\mathrm{a}=2.3575$ & $\mathrm{a}=10.7584$ & $\mathrm{a}=1.063$ & $\mathrm{a}=1.3988$ \\
\hline & constants & $b=2.3529$ & $b=5.8572$ & $b=2.6753$ & $b=3.5822$ & $b=6.4266$ & $b=2.0865$ \\
\hline & & $\mathrm{k}=0.2920$ & $\mathrm{k}=2.738$ & $\mathrm{k}=0.2132$ & $\mathrm{k}=0.0784$ & $\mathrm{k}=2.9432$ & $\mathrm{k}=0.6217$ \\
\hline
\end{tabular}



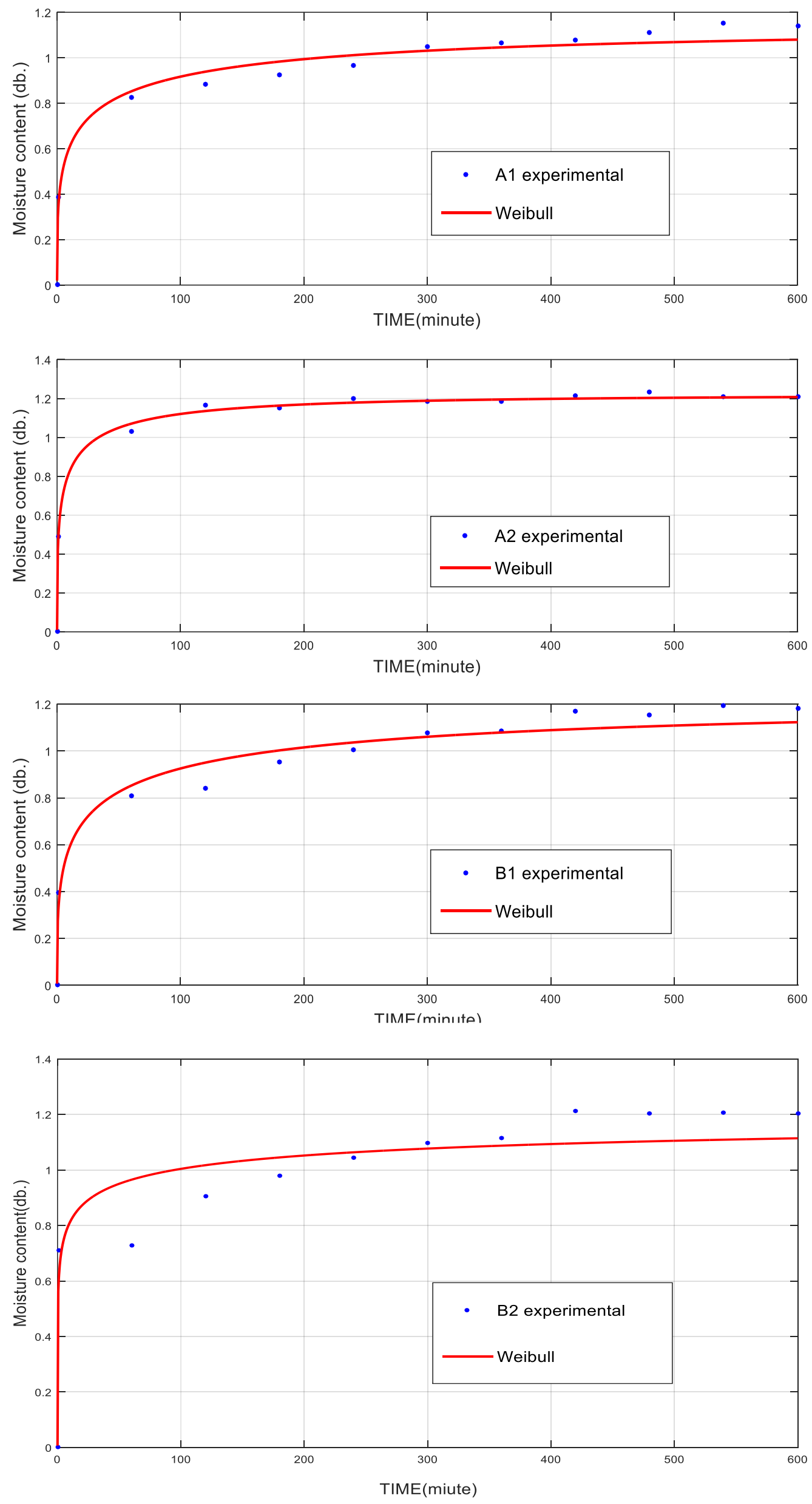

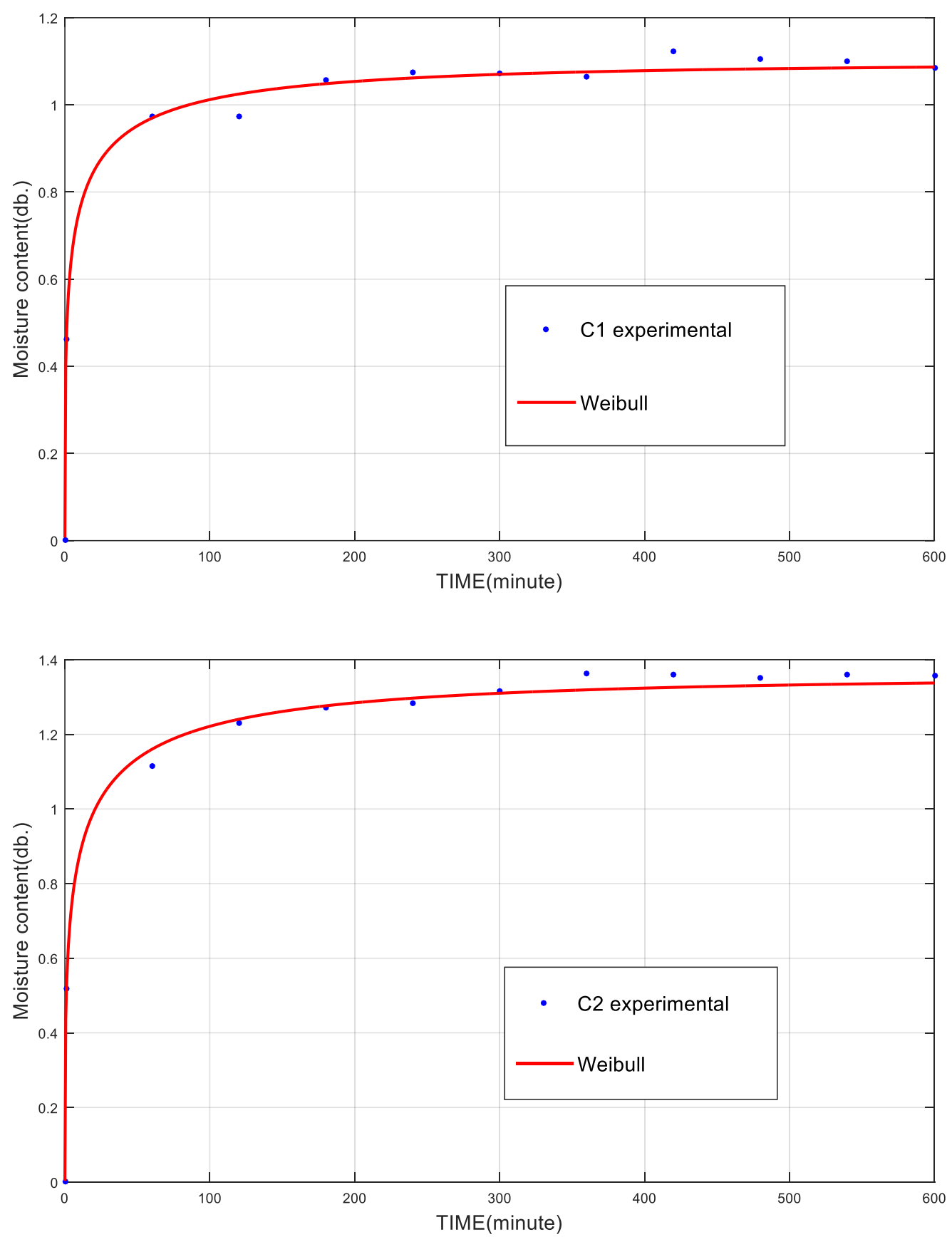

Figure 3. Experimental points of water uptake ( $\cdots$ ) and fitted Weibull model (-) for treated samples; A1, A2, B1, B2, $\mathrm{C} 1$ and $\mathrm{C} 2$.

Concerning microwave drying, Giri and Prasad. (2007) have reported that the increasing of microwave power vacuum-assisted drying of button mushroom, had increased the rehydration ratio. This finding had been attributed likely to the rapid evaporation (short time) of water and the less occurring of shrinkage (open structure) and hardening, which all had contributed to improve the rehydration characteristics. Similarly, the air-drying of oyster mushrooms had shown to be able to affect the texture and the colour of mushrooms, and subsequently the rehydration process (Kotwaliwale et al., 2007).

In contrary, Dadali et al. (2008) had reported that the water uptake was negatively affected by the amount of microwave dried spinach $(25-100 \mathrm{~g})$. It was indicated that the equilibrium moisture content had been decreasing by the increase of the samples amount. It was found too that Peleg's model was the more appropriate model $\left(\mathrm{R}^{2}\right)$ for experimental data over Weibull's model. It had been observed that the parameters "a" and "b" for Peleg's model, were increased by the increase of sample amounts. However, the increasing of output power had decreased these two parameters and also caused an increase in equilibrium moisture contents. An increase was observed with "b", parameter values, when the samples amount had been increased at fixed output (360W). Differently, in the findings of the present study, where the "b" parameter for 
Weibull model, were decreased by the increase of sample amount (A2, B2). However, $650 \mathrm{~W}(\mathrm{C} 2)$ has shown a small increase by increasing the amount.

Although the water rehydration temperature has not been tested in this work, it would give other results with these truffles, as it has been already proved by many studies. For instance, the study of García-Pascual et al. (2005) had proved that the changing of water temperature can change the equilibrium water content during rehydration of Boletus edulis mushroom.

\section{Conclusion}

On the basis of this work, after examining the dehydration conditions (power output and weights) effects on rehydration kinetics, it was found that the drying conditions can have effects on the dried material and also its rehydration kinetics and capacity. The increase of sample amount for each output power has increased the rehydration capacity. Samples treated at $650 \mathrm{~W}$ seemed to be a good example of this explanation. The less the amount of sample $(100 \mathrm{~g})$, the more drying effect $(6.5 \mathrm{~W} / \mathrm{g})$ and the less rehydration capacity (2.08). Weibull model has fitted all the type of treatments showing the highest regression coefficient $\left(\mathrm{R}^{2}\right)$. Its " $\mathrm{b}$ " constant may be linked to internal water diffusion for microwave dried truffles. Therefore, more investigations are needed to better understand the rehydration behaviours of these food materials. Also, the previous investigations of various rehydration conditions (e.g. temperature) had shown interesting results for different type of dried foodstuffs, so it can be an unavoidable subject for dried truffles.

\section{Acknowledgment}

The authors acknowledge the valuable help of Ahmed Hassan A. H. in coding and writing on MATLAB software.

\section{Declarations of interest: none}

\section{Funding}

This research did not receive any specific grant from funding agencies in the public, commercial, or not-forprofit sectors.

\section{References}

Akar G, Barutçu Mazı I. 2019. Color change, ascorbic acid degradation kinetics, and rehydration behavior of kiwifruit as affected by different drying methods. Journal of food process engineering, 42(3): e13011.

AL-Ruqaie IM. 2006. Effect of different treatment processes and preservation methods on the quality of truffles: I. Conventional methods (drying/freezing). Journal of food processing and preservation, 30(3): 335-351.

Ansari S, Maftoon-Azad N, Farahnaky A, Hosseini E, Asadi G. 2015. Modeling Rehydration Behavior of Dried Figs. Journal of Agricultural Science and Technology, 17(1): 133-144.

Aral S, Beşe AV. 2016. Convective drying of hawthorn fruit (Crataegus spp.): effect of experimental parameters on drying kinetics, color, shrinkage, and rehydration capacity. Food Chemistry, 210: 577-584.

Arballo JR, Campañone LA, Mascheroni RH. 2010. Modeling of microwave drying of fruits. Drying Technology, 28(10): $1178-1184$.
Bal C, Akgul H, Sevindik M, Akata I, Yumrutas O. 2017. Determination of the anti-oxidative activities of six mushrooms. Fresen. Environ. Bull, 26: 6246-6252.

Benseddik A, Azzi A, Zidoune M, Khanniche R, Besombes C. 2019. Empirical and diffusion models of rehydration process of differently dried pumpkin slices. Journal of the Saudi Society of Agricultural Sciences, 18(4): 401-410.

Bradai L. 2014. Inventaire et bioecologie des terfez dans quelques regions du sahara septentrional. Doctoral dissertation.

Bradai L, Bissati S, Chenchouni H, Amrani K. 2015a. Effects of climate on the productivity of desert truffles beneath hyperarid conditions. International journal of biometeorology, 59(7): 907-915.

Bradai L, Neffar S, Amrani K, Bissati S, Chenchouni H. 2015b. Ethnomycological survey of traditional usage and indigenous knowledge on desert truffles among the native Sahara Desert people of Algeria. Journal of ethnopharmacology, 162: 3138.

Bradali L, Bissati S, Chenchouni H. 2013. Etude mycologique et bio-écologique de la truffe blanche du désert (Tirmania nivea Desf. Trappe 1971) dans la région de Oued M'ya (Ouargla, Sahara algérien). Revue des Bioressources, 257(1621): 1-17.

Chatin M. 1891. Contribution à l'histoire botanique de la truffe: kamé de Damas (Terfezia claveryi). Bulletin de la Société Botanique de France, 38(8): 332-335.

Chatin M. 1892. Nouvelle Contribution A L'Histoire De La Truffe; Tirmania Cambonii; Terfas Du Sud Algérien. Bulletin de la Société Botanique de France, 39(7): 275-277.

Dadali G, Demirhan E, Özbek B. 2007. Microwave heat treatment of spinach: drying kinetics and effective moisture diffusivity. Drying Technology, 25(10): 1703-1712.

Dadali G, Demirhan E, Özbek B. 2008. Effect of drying conditions on rehydration kinetics of microwave dried spinach. food and bioproducts processing, 86(4): 235-241.

Dafri A, Beddiar A. 2017. Desert truffles from northeastern Algerian coasal dunes: Ecology, identification and symbiosis. Journal of Fundamental and Applied Sciences, 9(1): 154-169.

Dev S, Geetha P, Orsat V, Gariépy Y, Raghavan G. 2011. Effects of microwave-assisted hot air drying and conventional hot air drying on the drying kinetics, color, rehydration, and volatiles of Moringa oleifera. Drying Technology, 29(12): 1452-1458.

Diaz G R, Martınez-Monzo J, Fito P, Chiralt A. 2003. Modelling of dehydration-rehydration of orange slices in combined microwave/air drying. Innovative Food Science \& Emerging Technologies, 4(2): 203-209.

Díez J, Manjón JL, Martin F. 2002. Molecular phylogeny of the mycorrhizal desert truffles (Terfezia and Tirmania), host specificity and edaphic tolerance. Mycologia, 94(2): 247-259.

García-Pascual P, Sanjuán N, Melis R, Mulet A. 2006. Morchella esculenta (morel) rehydration process modelling. Journal of Food Engineering, 72(4): 346-353.

García-Segovia P, Andrés-Bello A, Martínez-Monzó J. 2011. Rehydration of air-dried Shiitake mushroom (Lentinus edodes) caps: Comparison of conventional and vacuum water immersion processes. LWT-Food Science and Technology, 44(2): 480-488.

García-Pascual P, Sanjuán N, Bon J, Carreres J E, Mulet A. 2005. Rehydration process of Boletus edulis mushroom: characteristics and modelling. Journal of the Science of Food and Agriculture, 85(8): 1397-1404.

Giri S, Prasad S. 2007. Drying kinetics and rehydration characteristics of microwave-vacuum and convective hot-air dried mushrooms. Journal of food engineering, 78(2): 512521.

Goula AM, Adamopoulos KG. 2009. Modeling the rehydration process of dried tomato. Drying Technology, 27(10): 10781088.

Hussain G, Al-Ruqaie IM. 1999. Occurrence, chemical composition, and nutritional value of truffles: an overview. Paki. J. Biol. Sci, 2(2): 510-514. 
Kocabay ÖG, Ismail O. 2017. Investigation of rehydration kinetics of open-sun dried okra samples. Heat and Mass Transfer, 53(6): 2155-2163.

Kotwaliwale N, Bakane P, Verma A. 2007. Changes in textural and optical properties of oyster mushroom during hot air drying. Journal of Food Engineering, 78(4): 1207-1211.

Kowalska H, Marzec A, Kowalska J, Ciurzyńska A, Samborska K, Bialik M, Lenart A. 2018. Rehydration properties of hybrid method dried fruit enriched by natural components. International Agrophysics, 32(2): 175-182.

Krokida M, Philippopoulos C. 2005. Rehydration of dehydrated foods. Drying Technology, 23(4): 799-830.

Lopez-Quiroga E, Prosapio V, Fryer P, Norton I, Bakalis S. 2019. A model-based study of rehydration kinetics in freeze-dried tomatoes. Energy Procedia, 161: 75-82.

Mandeel QA, Al-Laith AAA. 2007. Ethnomycological aspects of the desert truffle among native Bahraini and non-Bahraini peoples of the Kingdom of Bahrain. Journal of ethnopharmacology, 110(1): 118-129.

Marabi A, Livings S, Jacobson M, Saguy I. 2003. Normalized Weibull distribution for modeling rehydration of food particulates. European Food Research and Technology, 217(4): 311-318.

Maskan M. 2001. Drying, shrinkage and rehydration characteristics of kiwifruits during hot air and microwave drying. Journal of food engineering, 48(2): 177-182.

Moreira R, Chenlo F, Chaguri L, Fernandes C. 2008. Water absorption, texture, and color kinetics of air-dried chestnuts during rehydration. Journal of Food Engineering, 86(4): 584594.

Noshad M, Mohebbi M, Shahidi F, Mortazavi SA. 2012. Kinetic modeling of rehydration in air-dried quinces pretreated with osmotic dehydration and ultrasonic. Journal of Food Processing and Preservation, 36(5): 383-392.

Palacios I, Guillamón E, García-Lafuente A, Villares A. 2014. Effects of Freeze-Drying Treatment on the Aromatic Profile of $\mathrm{T}$ uber spp. Truffles. Journal of food processing and preservation, 38(3): 768-773.

Patel S, Rauf A, Khan H, Khalid S, Mubarak M S. 2017. Potential health benefits of natural products derived from truffles: a review. Trends in Food Science \& Technology, 70: 1-8.

Peleg M. 1988. An empirical model for the description of moisture sorption curves. Journal of Food science, 53(4): 1216-1217.

Pramiu P, Rizzi R, Do Prado N, Coelho S, Bassinello P. 2015. Numerical modeling of chickpea (Cicer arietinum) hydration: The effects of temperature and low pressure. Journal of Food Engineering, 165: 112-123.
Reale A, Sorrentino E, Iacumin L, Tremonte P, Manzano M, Maiuro L, Comi G, Coppola R, Succi M. 2009. Irradiation treatments to improve the shelf life of fresh black truffles (truffles preservation by gamma-rays). Journal of food science, 74(4): M196-M200.

Rivera CS, Blanco D, Salvador ML, Venturini ME. 2010. ShelfLife Extension of Fresh Tuber aestivum and Tuber melanosporum Truffles by Modified Atmosphere Packaging with Microperforated Films. Journal of Food Science, 75(4): E225-E233.

Saguy IS, Marabi A, Wallach R. 2005. New approach to model rehydration of dry food particulates utilizing principles of liquid transport in porous media. Trends in Food Science \& Technology, 16(11): 495-506.

Saguy IS, Troygot O, Marabi A, Wallach R. 2010. Rehydration Modeling of Food Particulates Utilizing Principles of Water Transport in Porous Media Food Engineering Interfaces (pp. 535-552): Springer.

Sevindik M, Akgul H, Bal C, Selamoglu Z. 2018. Phenolic contents, oxidant/antioxidant potential and heavy metal levels in Cyclocybe cylindracea. Indian Journal of Pharmaceutical Education and Research, 52(3): 437-441.

Shavit E, Shavit E. 2014. The medicinal value of desert truffles. In: Kagan-Zur V., Roth-Bejerano N. Sitrit Y. Morte A. Desert Truffles. Berlin, Heidelberg: Springer. pp. 323-340.

Trappe JM, Castellano MA. 1991. Keys to the genera of truffles (Ascomycetes). McIlvanea, 10: 47-65.

Vega-Gálvez A, Notte-Cuello E, Lemus-Mondaca R, Zura L, Miranda M. 2009. Mathematical modelling of mass transfer during rehydration process of Aloe vera (Aloe barbadensis Miller). Food and Bioproducts Processing, 87(4): 254-260.

Yalçın ZG, Çorbacıoğlu BD, Aydoğmuş E, Mustafa D. 2018. The Study of Dehydration and Rehydration Kinetics of Phaseolus Vulgaris. Journal of Current Researches on Engineering, Science and Technology, 4(1): 1-18.

Zielinska M, Markowski M. 2016. The influence of microwaveassisted drying techniques on the rehydration behavior of blueberries (Vaccinium corymbosum L.). Food chemistry, 196: 1188-1196.

Zitouni-Haouar FEH, Fortas Z, Chevalier G. 2014. Morphological characterization of mycorrhizae formed between three Terfezia species (desert truffles) and several Cistaceae and Aleppo pine. Mycorrhiza, 24(5): 397-403. 